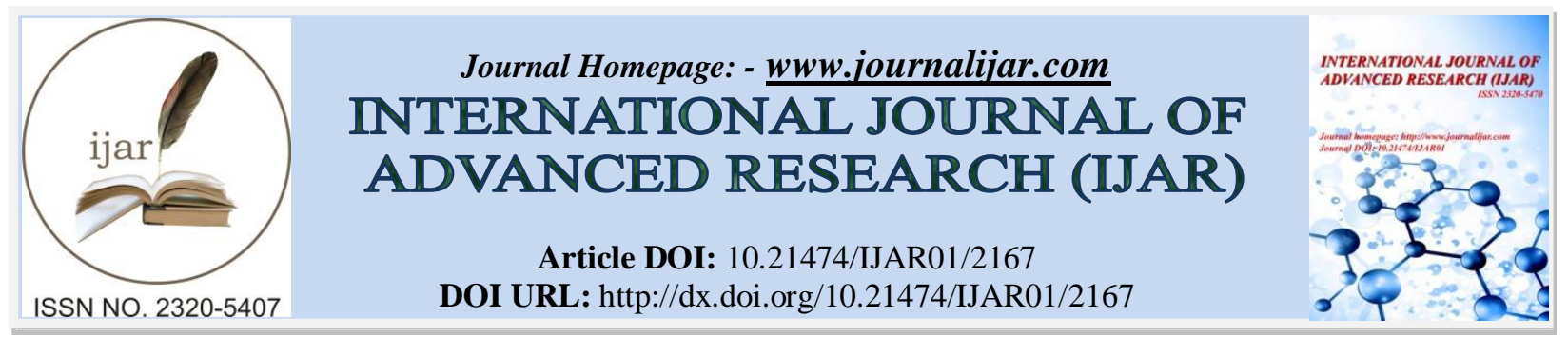

RESEARCH ARTICLE

\title{
SYNTHESIS AND ANTIMICROBIAL ACTIVITY OF SOME PHENOLIC MANNICH BASES.
}

\author{
${ }^{*}$ Abdel Karim. M. ${ }^{1}$, Wafa, O. $^{2}$, Nafesa. A. G. ${ }^{3}$ and Inas. O. ${ }^{4}$ \\ 1. Sudan University of Science and Technology, Faculty of Science. \\ 2. Kordofan University, Faculty of Education. \\ 3. Bisha University, Faculty of Science. \\ 4. University of Bahri, Faculty of Applied and Industrial Chemistry.
}

\section{Manuscript Info}

\section{Manuscript History}

Received: 26 September 2016

Final Accepted: 29 October 2016

Published: November 2016

Key words:-

Mannich Bases, Phenolic , Synthesis ,

Antimicrobial Activity

\begin{abstract}
Four phenolic Mannich bases: 3-(hydroxymethyl)-1-(morpholin-4ylmethyl)naphthalen-2-yl acetate ;(2-(diethylaminomethyl) phenyl -1 acetate ; 1-[(piperidin-1-yl) methyl]naphthalen-2-ol; N,N-dimethyl-1(naphthalen-2-yloxy)methanamine were synthesized via a general synthesis protocol involving a single pot facile condensation of an active hydrogen component with a secondary amine in presence of formalin. The constitution of the target molecules was established on the basis of their spectral data(UV, IR, NMR and MS). The Mannich bases were evaluated for their antimicrobial activity using the cup plate agar diffusion method. Compound IV showed excellent antibacterial activity against all test organisms. It was also active against the fungal species Aspergillus niger. The same trend was observed for compound II which showed activity against both fungal species. Compound I demonstrated significant activity against Staphylococcus aureus. Compound III demonstrated different promising antimicrobial responses.
\end{abstract}

Copy Right, IJAR, 2016,. All rights reserved.

\section{Introduction:-}

The Mannich reaction is a single pot three component condensation in which ammonia, a primary or secondary amine reacts with formaldehyde and a compound containing at least one hydrogen atom of pronounced reactivity. The essential feature of the reaction is the replacement of the active hydrogen atom by an aminomethyl or substituted aminomethyl moiety.

The product from acetophenone, formaldehyde, and a secondary amine is an example.Mannich bases are known for their potential biological activity. Some Mannich bases possess antibacterial activity ( Lorand and Kocsis,2002; Laura et.al.,2009 ; Barijesh et.al.,2004; Pernak et.al.,1999 ; Surendra et.al.,2000 ; Pandeya et.al.,1999a ; Pandeya et.al.,1999b). Some bases were identified as potent antimalarial agents(Delarue et.al.,2008 ; Kaylene et.al.,1999 ; Chipeleme and Phillip,2007; Li-Zhong et.al.,2003). Mannich bases with putative cytotoxic activity were reported(Jonathan et.al.,2002 ; Dimmock et.al.,1995 ; Dimmock et.al., 2000 ; Gul et.al.,2000) . Some Mannich bases demonstrated potential anticonvulsant activity while others are claimed to exhibit antiamoebic potency(Archana and Kumar,2004; Abid-Abdulroouf and Azam,2009)

In continuation of our interest in biologically active Mannich bases, this work was designed to synthesize some phenolic Mannich bases and evaluation of biological activity.

Corresponding Author:- Abdel Karim. M.

Address:- Sudan University of Science and Technology, Faculty of Science. 


\section{Materials and Methods:-}

Analytical grade reagents were used. They were purchased from Sigma- Aldrich Company (UK). Melting points were recorded in open capillary tubes and were uncorrected. The IR spectra were recorded on a Perkin-Elmer FT-IR spectrophotometer using (KBr) disc. The ${ }^{1}$ HNMR spectra were recorded on a Brucker AMX (400 MHZ) spectrophotometer using DMSO as a solvent and TMS as internal reference.Mass spectra were recorded on a Shimadzu GC.M.QP 1000 mass spectrometer at $70 \mathrm{ev.}$

The purity of the compounds was checked by thin layer chromatography (TLC), using ethyl acetate, chloroform and methanol as a mobile phase.

Synthesis of Mannich base I ( 3-(hydroxymethyl)-1-(morpholin-4-ylmethyl)naphthalen-2-yl acetate):Formalin $(3.2 \mathrm{~g}, 20 \mathrm{mmol}), \beta$ - naphthol $(2.88 \mathrm{~g}, 20 \mathrm{mmol})$ and morpholine $(1.74 \mathrm{~g}, 20 \mathrm{mmol})$ in $20 \mathrm{ml}$ ethanol were left at room temperature for 7 days. Removal of the solvent under reduced pressure gave the Mannich base.

$(2.94 \mathrm{~g})$ of Mannich base were suspended in $5 \mathrm{ml}(3 \mathrm{M}) \mathrm{NaOH}$ solution. Crushed ice was added followed by (4.4 $\mathrm{ml}$ ) acetic anhydride. The mixture was shaked vigorously for 60 seconds. The acetate was separated after acidification by hydrochloric acid. The acetyl derivative was collected and recrystallized from dilute ethanol.

Synthesis of Mannich base II (2-(diethyl aminomethyl) phenyl -1 acetate):-

Formalin $(3.2 \mathrm{~g}, 20 \mathrm{mmol})$, phenol $(2.88 \mathrm{~g}, 20 \mathrm{mmol})$ and diethylamine $(1.46 \mathrm{~g}, 20 \mathrm{mmol})$ in $20 \mathrm{ml}$ ethanol were left at room temperature for four days. Removal of the solvent under reduced pressure gave the Mannich base.

$(1.78 \mathrm{~g}$ ) of Mannich base were suspended in $5 \mathrm{ml}(3 \mathrm{M}) \mathrm{NaOH}$ solution. Crushed ice was added followed by ( 2.48 $\mathrm{ml}$ ) acetic anhydride. The mixture was shaked vigorously for 60 seconds. The acetate was separated after acidification by hydrochloric acid. The acetyl derivative was collected and recrystallized from dilute ethanol.

Synthesis of Mannich base III(1-[(piperidin-1-yl) methyl] naphthalen-2-ol):-

Formalin (3.2 g,20 mmol), $\beta$ - naphthol $(2.88 \mathrm{~g}, 20 \mathrm{mmol})$ and piperidine $(1.68 \mathrm{~g}, 20 \mathrm{mmol})$ in $20 \mathrm{ml}$ ethanol were left at room temperature for six days. Removal of the solvent under reduced pressure gave the Mannich base.

Synthesis of Mannich base IV ( $N, N$-dimethyl-1-(naphthalen-2-yloxy)methanamine):-

Formalin $(3.2 \mathrm{~g}, 20 \mathrm{mmol}), \beta$ - naphthol $(2.88 \mathrm{~g}, 20 \mathrm{mmol})$ and dimethylamine $(0.9 \mathrm{~g}, 20 \mathrm{mmol})$ in $20 \mathrm{ml}$ ethanol were left at room temperature for 7 days. Removal of the solvent under reduced pressure gave the Mannich base.

Antimicrobial assay:-

Compounds I-IV were screened for antimicrobial activity against six standard human pathogens (Bacillus subtilis, Staphylococcus aureus, Pseudomonas aeruginosa, Escherichia coli, Aspergillas niger and Candida albicans).

\section{Preparation of bacterial suspensions:-}

One $\mathrm{ml}$ aliquots of a 24 hours broth culture of the test organisms were aseptically distributed onto nutrient agar slopes and incubated at $37^{\circ} \mathrm{C}$ for 24 hours. The bacterial growth was harvested and washed off with $100 \mathrm{ml}$ sterile normal saline, to produce a suspension containing about $10^{8}-10^{9}$ C.F.U/ $\mathrm{ml}$. The suspension was stored in the refrigerator at $4^{\circ} \mathrm{C}$ till used. The average number of viable organisms per $\mathrm{ml}$ of the stock suspension was determined by means of the surface viable counting technique(Wikler,2007). Serial dilutions of the stock suspension were made in sterile normal saline solution and $(0.02 \mathrm{ml})$ volumes of the appropriate dilution were transferred by micro pipette onto the surface of dried nutrient agar plates. The plates were allowed to stand for two hours at room temperature for the drops to dry and then incubated at $37^{\circ} \mathrm{C}$ for 24 hours. After incubation, the number of developed colonies in each drop was counted. The average number of colonies per drop $(0.02 \mathrm{ml})$ was multiplied by 50 and by the dilution factor to give the viable count of the stock suspension, expressed as the number of colony forming units per $\mathrm{ml}$ suspension. Each time a fresh stock suspension was prepared. All the above experimental conditions were maintained constant so that suspensions with very close viable counts would be obtained.

\section{Preparation of fungal suspension:-}

The fungal cultures were maintained on dextrose agar, incubated at $25{ }^{\circ} \mathrm{C}$ for 4 days. The fungal growth was harvested and washed with sterile normal saline and finally suspended in $(100 \mathrm{ml})$ of sterile normal saline, and the suspensions were stored in the refrigerator until used. 


\section{Testing of antibacterial activity:-}

The experiment was carried out according to the National Committee for Clinical Laboratory Standards Guidelines(Wikler,2007).. Bacterial suspension was diluted with sterile physiological solution to $10 \mathrm{cfu} / \mathrm{ml}$ (turbidity = McFarland standard 0.5). One hundred microliters of bacterial suspension were swabbed uniformly on surface of MHA and the inoculum was allowed to dry for 5 minutes. Sterilized filter paper discs (Whatman No.1, 6 $\mathrm{mm}$ in diameter) were placed on the surface of the MHA and soaked with ( $20 \mu \mathrm{l})$ of test solution. The plates were incubated at $37{ }^{\circ} \mathrm{C}$ for $24 \mathrm{~h}$ in the inverted position. The diameters $(\mathrm{mm})$ of the inhibition zones were measured in triplicates and averaged.

\section{Testing of antifungal activity:-}

The above mentioned method was adopted for antifungal activity, but instead of agar, dextrose agar was used. Samples were used here by the same concentrations used above.

\section{Results and discussion :-}

The synthesis, characterization and antimicrobial activity of the target molecules are discussed below . A tabulation of the physical data of the synthesized compounds is shown in Table1.The formation of all target molecules was confirmed by IR, ${ }^{1} \mathrm{HNMR}$ and Mass spectroscopy data.

Table 1: the physiochemical data of synthesized compounds

\begin{tabular}{|c|l|l|}
\hline compound & Melting point $\left({ }^{\circ} \mathrm{C}\right)$ & Molecular Formula \\
\hline I & $193-194$ & $\mathrm{C}_{18} \mathrm{H}_{21} \mathrm{NO}_{4}$ \\
\hline II & $138-140$ & $\mathrm{C}_{13} \mathrm{H}_{19} \mathrm{NO}_{2}$ \\
\hline III & $105-107$ & $\mathrm{C}_{16} \mathrm{H}_{19} \mathrm{NO}$ \\
\hline IV & $108-109$ & $\mathrm{C}_{13} \mathrm{H}_{15} \mathrm{NO}$ \\
\hline
\end{tabular}

Synthesis of the Mannich base I (3-(hydroxymethyl)-1-(morpholin-4-ylmethyl)naphthalen-2-yl acetate):-<smiles>CC(=O)Oc1c(CO)cc2ccccc2c1CN1CCOCC1</smiles>

(I)

The Mannich base I was synthesized by adding formalin to a mixture of $\beta$ - naphthol and morpholine in absolute ethanol.The base was isolated after acetylation. The UV spectrum of base I (Fig.1) showed $\lambda_{\max }(\mathrm{MeOH})$ $236,276,327 \mathrm{~nm}$.

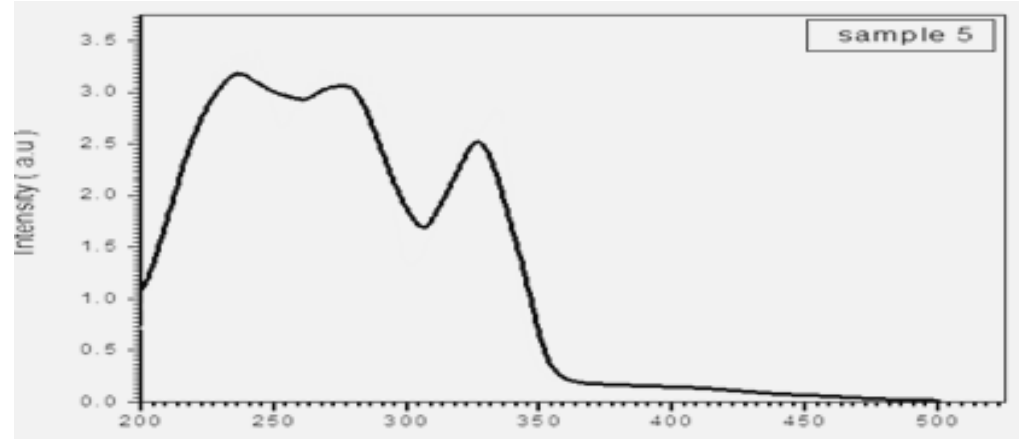

Fig 1: The UV spectrum of Mannich base I

The IR spectrum (Fig.2) showed $v(\mathrm{KBr}) 703,752,823,864(\mathrm{C}-\mathrm{H}$, Ar. bending), $1251(\mathrm{C}-\mathrm{N}), 1514,1579,1606$ (C=C, Aromatic), $1698(\mathrm{C}=\mathrm{O}), 2750,2882\left(\mathrm{C}-\mathrm{H}\right.$, aliphatic), $3450 \mathrm{~cm}^{-1}(\mathrm{OH})$. 


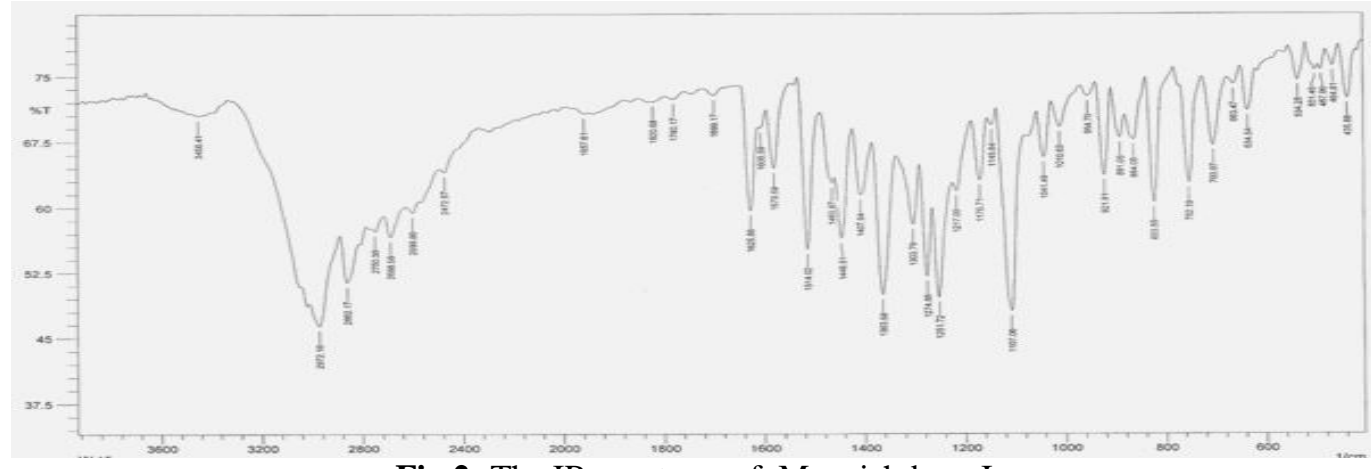

Fig 2: The IR spectrum of Mannich base I

The ${ }^{1}$ HNMR spectrum (Fig. 3) showed: $\delta 3.05(3 \mathrm{H})$ assigned for a methyl function $(\alpha$ - to carbonyl) ; $\delta 3.25(6 \mathrm{H})$ accounting for three methylenes (shifted downfield by nitrogen electron-withdrawal effect ); $\delta 3.80(6 \mathrm{H})$ attributed to three methylenes .The aromatic protons appeared at : $\delta 7.33, \delta 7.51,7.85$ and $8.23 \mathrm{ppm}$. The Mass spectrum (Fig 4) gave $\mathrm{m} / \mathrm{z} 317$ for the $\left(\mathrm{M}^{+}+2 \mathrm{H}\right)$.

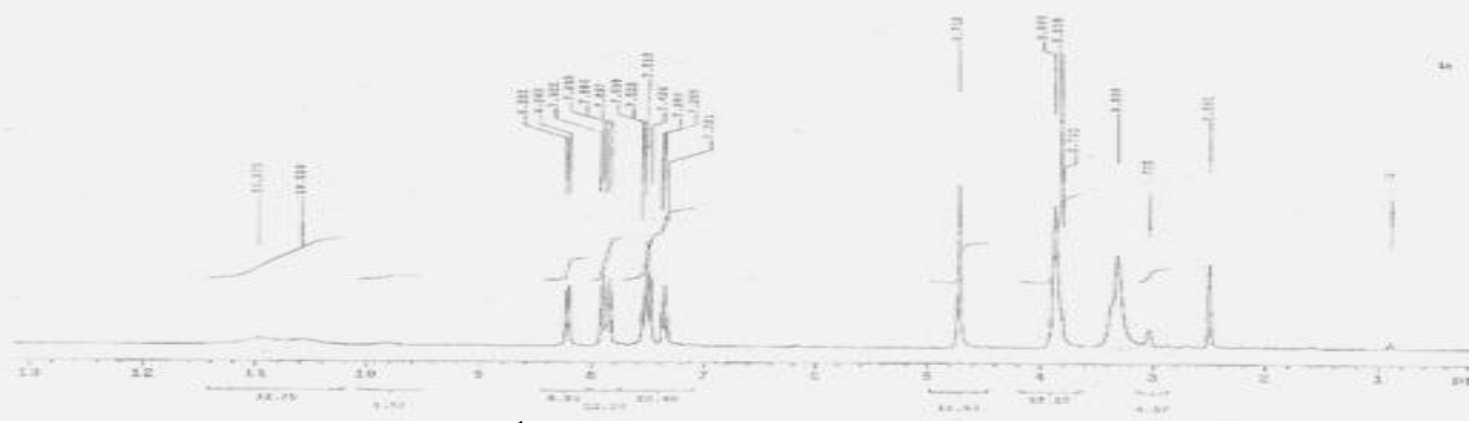

Fig.3: ${ }^{1}$ HNMR spectrum of Mannich base I

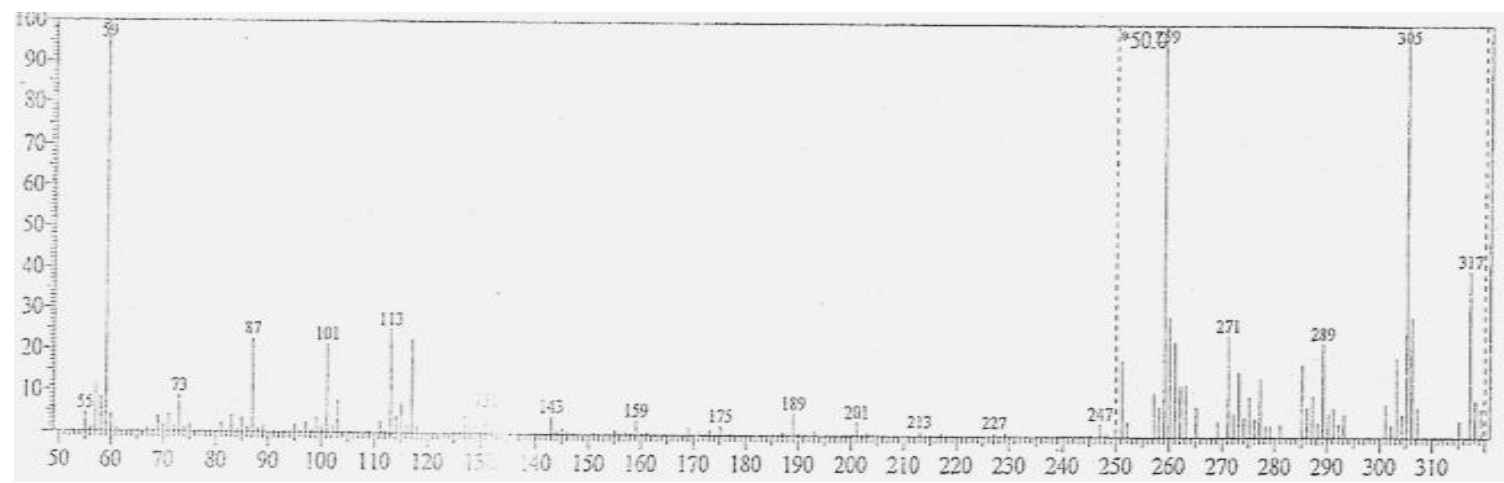

Fig.4: The Mass spectrum of Mannich base I

On the basis of the above spectral data structure I above was assigned for this Mannich base.

\section{Synthesis of the Mannich base II (2-(diethyl aminomethyl) phenyl -1 acetate):-}<smiles>CCN(CC)Cc1ccccc1OC</smiles> 
The Mannich base II was synthesized by adding formalin to a mixture of phenol and diethylamine in absolute ethanol.The base was isolated after acetylation. The UV spectrum (Fig.5) showed $\lambda_{\max }(\mathrm{MeOH}) 237,280 \mathrm{~nm}$.

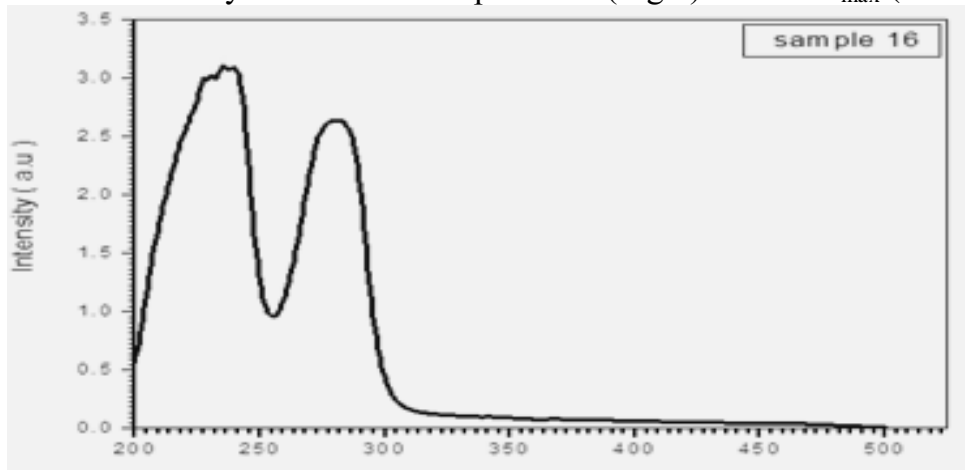

Fig. 5: The UV spectrum of Mannich base II

The IR spectrum (Fig .6) showed $v(\mathrm{KBr})$ : 761,827 (C-H, Ar., bending), $1269(\mathrm{C}-\mathrm{N}), 1510,1577(\mathrm{C}=\mathrm{C} \mathrm{Ar})$, 1600(C=O) , 2935, $2979 \mathrm{~cm}^{-1}(\mathrm{C}-\mathrm{H}$,aliphatic).

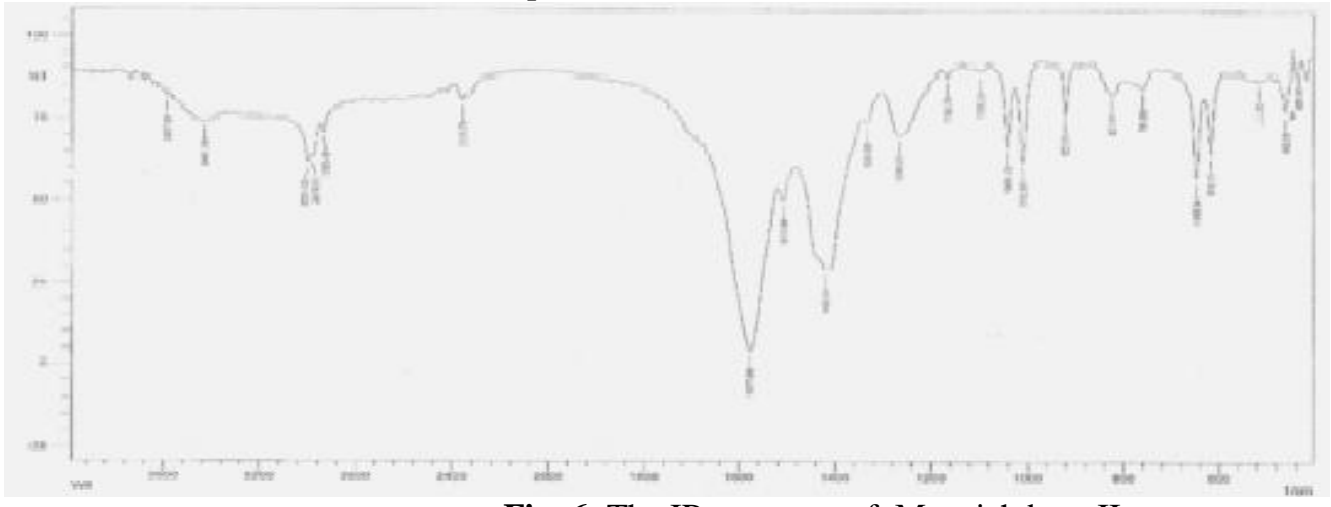

Fig. 6: The IR spectrum of Mannich base II

The ${ }^{1} \mathrm{HNMR}$ spectrum (Fig.7) showed: $\delta 1.00(6 \mathrm{H})$ accounting for two methyl functions ; $\delta 1.67(9 \mathrm{H})$ assigned for three methylene moieties and one $\alpha$ - to carbonyl methyl function. The aromatic protons appeared as multiplet at : 86.63-6.94ppm. The Mass spectrum (Fig 8) gave m/z 221 for $\mathrm{M}^{+}$.

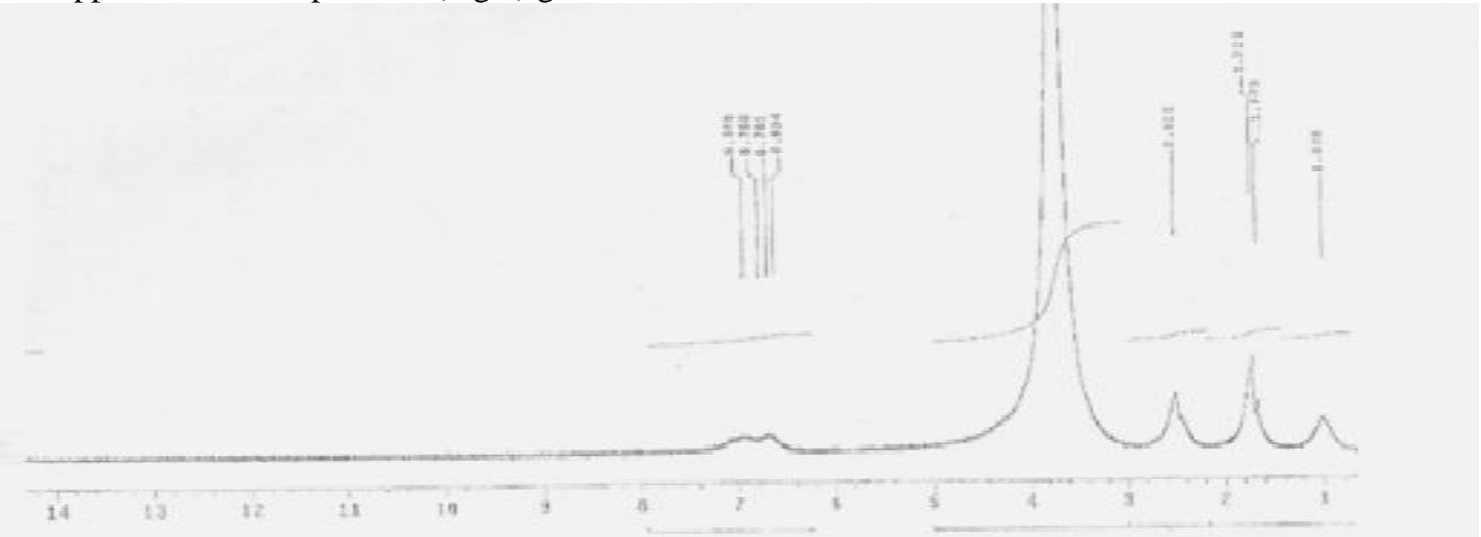

Fig.7: ${ }^{1}$ HNMR spectrum of Mannich base II 


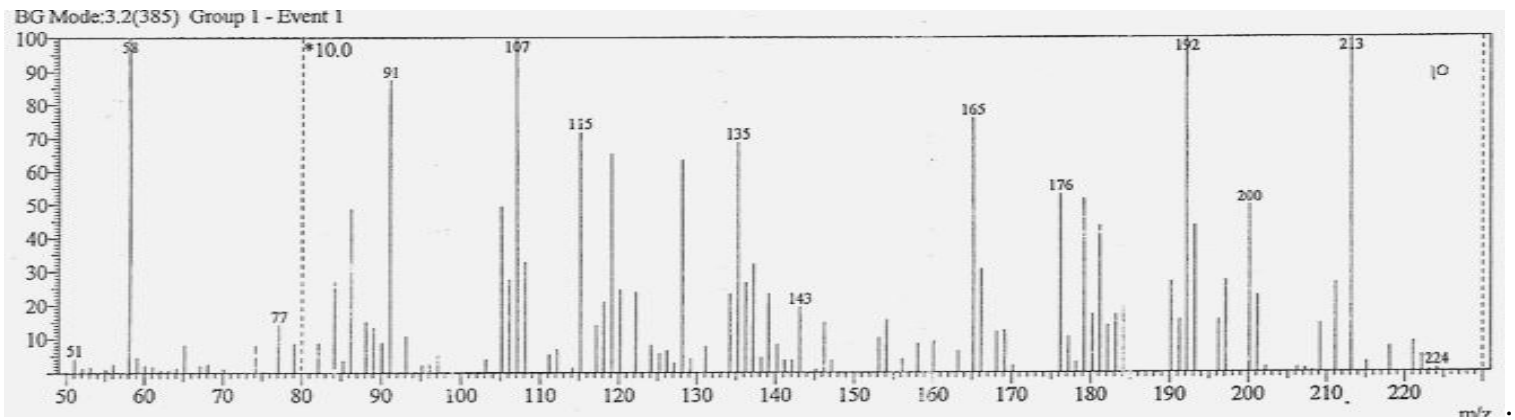

Fig.8: The Mass spectrum of Mannich base II

On the basis of the above spectral data structure II above was assigned for this Mannich base.

Synthesis of the Mannich base III(1-[(piperidin-1-yl) methyl] naphthalen-2-ol):-<smiles>Oc1ccc2ccccc2c1CN1CCCCC1</smiles>

(III)

The Mannich base III was synthesized by adding formalin to a mixture of $\beta$ - naphthol and piperidine in absolute ethanol.The UV spectrum (Fig.9) showed $\lambda_{\max }(\mathrm{MeOH}) 240.5,277.5,329.2 \mathrm{~nm}$.

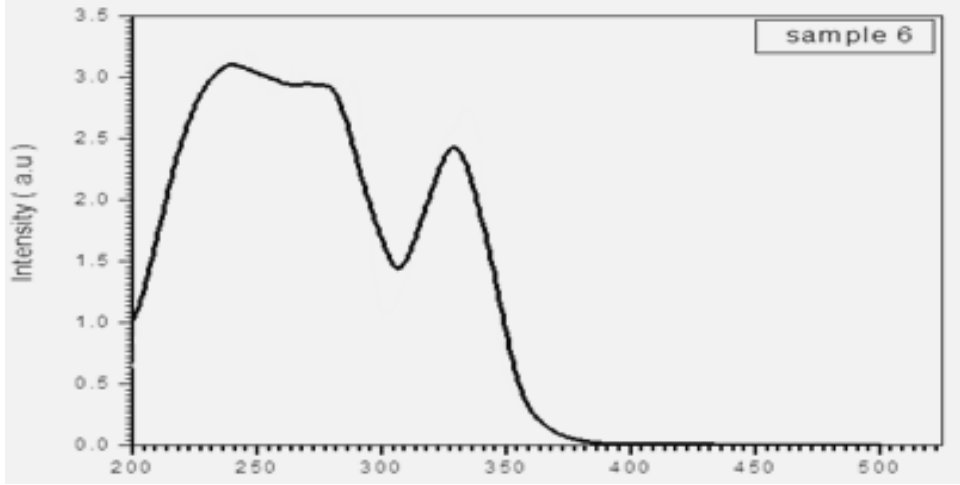

Fig.9: The UV spectrum of Mannich base III

The IR spectrum (Fig. 10) showed $v(\mathrm{KBr}) 707,738,765,786,811,856(\mathrm{C}-\mathrm{H}, \mathrm{Ar}$, bending). 1276(C-N). 1517, 1595(C=C, Ar). 2831, 2854, 2933(C-H, aliphatic), $3053 \mathrm{~cm}^{-1}(\mathrm{OH}$, hydrogen bonded) .

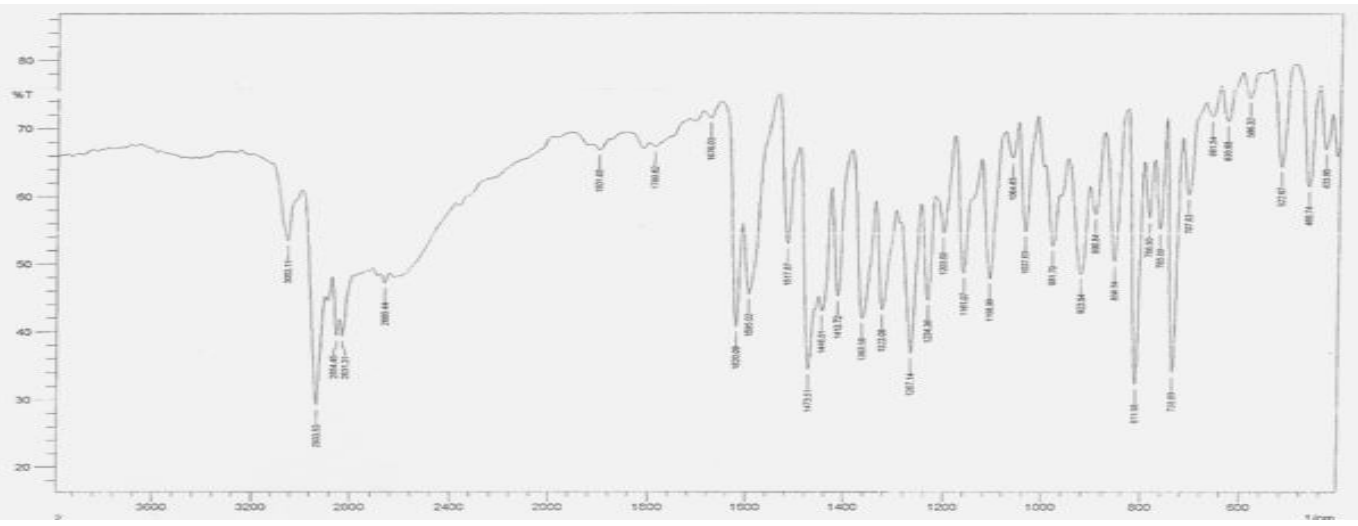

Fig.10: IR spectrum of Mannich base III 
The ${ }^{1} \mathrm{HNMR}$ spectrum (Fig. 11) showed: $\delta 1.45(6 \mathrm{H})$ assigned for $\left(\mathrm{CH}_{2}{ }^{\mathrm{CH}_{2}}\right) ; \delta 3.99(6 \mathrm{H})$ accounting for the methylene bridge and the remaining methylenes of the piperidine moiety. The aromatic protons appeared at $: \delta$ 6.98,7.29,7.39,7.44,7.67 and 7.91ppm. The Mass spectrum (Fig.12) gave m/z 241 for the molecular ion.

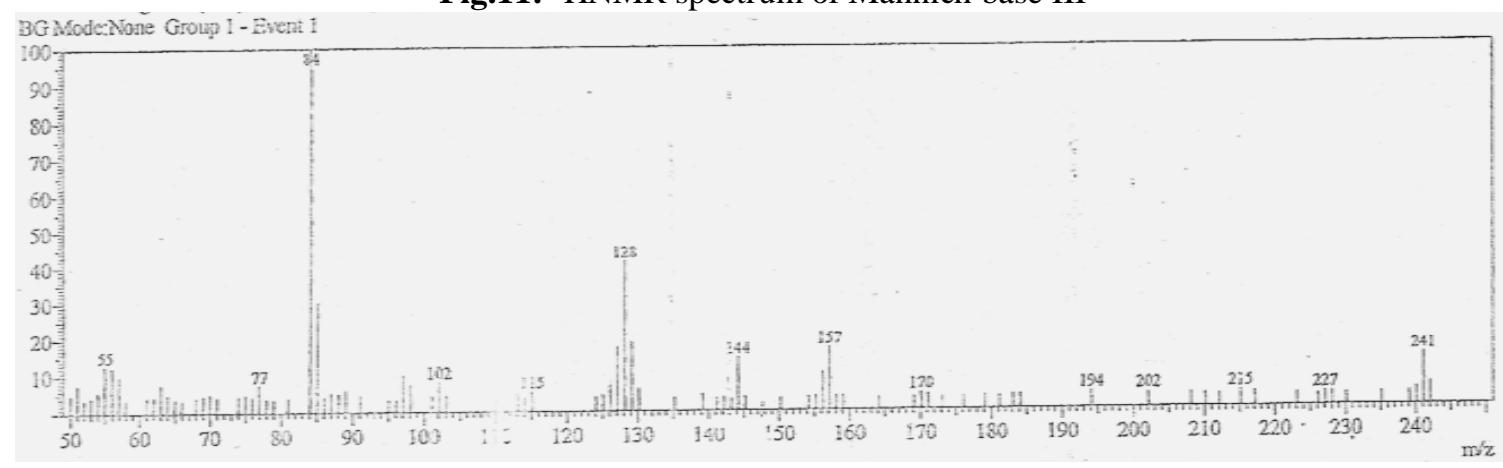

Fig.12: Mass spectrum of Mannich base III

On the basis of the above spectral data structure III above was assigned for this Mannich base.

Synthesis of the Mannich base IV ( $N, N$-dimethyl-1-(naphthalen-2-yloxy)methanamine)<smiles>CN(C)COc1ccc2ccccc2c1</smiles>

(IV)

The Mannich base IV was synthesized by adding formalin to a mixture of $\beta$ - naphthol and dimethylamine in absolute ethanol. The UV spectrum (Fig.13) showed $\lambda_{\max }(\mathrm{MeOH}) 239,277,332 \mathrm{~nm}$.

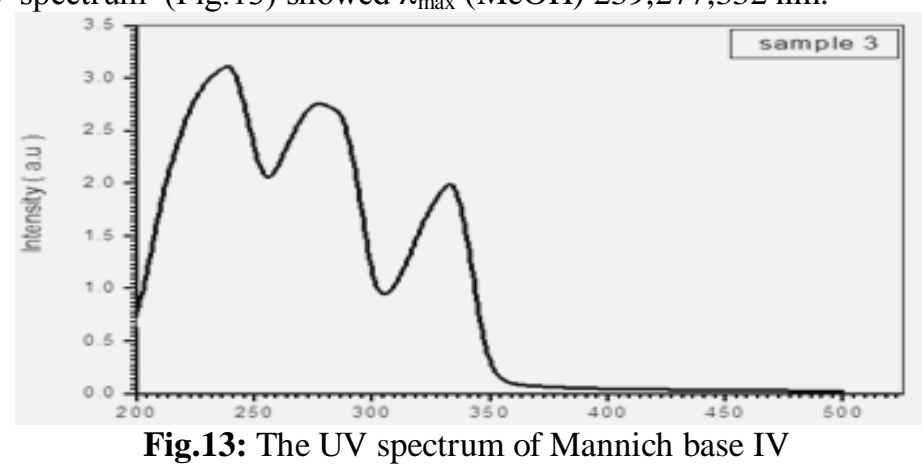


The IR spectrum (Fig. 14) showed $v(\mathrm{KBr}): 667,742,810,858(\mathrm{C}-\mathrm{H}$ Ar bending), $1355(\mathrm{C}-\mathrm{N}), 1512,1593(\mathrm{C}=\mathrm{C}$ Ar.,), 2941 (C-H, aliphatic).

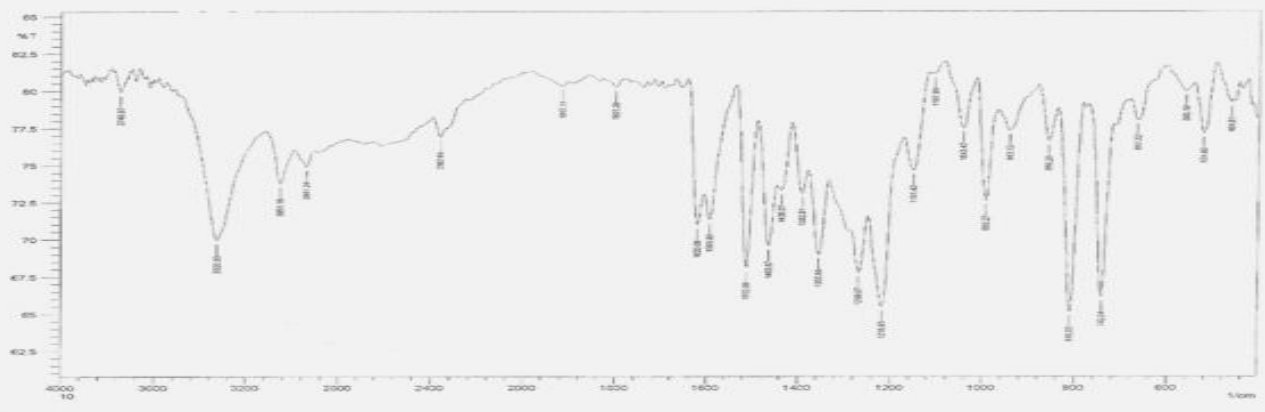

Fig 14: The IR spectrum of Mannich base IV

The ${ }^{1}$ HNMR spectrum (Fig.15) showed: $\delta 3.30(6 \mathrm{H})$ assigned for two methyl groups(shifted downfield by electron withdrawal of $\mathrm{N}) ; \delta 4.81(2 \mathrm{H})$ accounting for a methylene moiety (shifted downfield by electron withdrawal effect of both nitrogen and oxygen). The aromatic protons appeared at : $\delta 7.39, \delta 7.59,7.83$ and 8.20. The Mass spectrum (Fig 16) gave $\mathrm{m} / \mathrm{z} 201$ for the molecular ion.

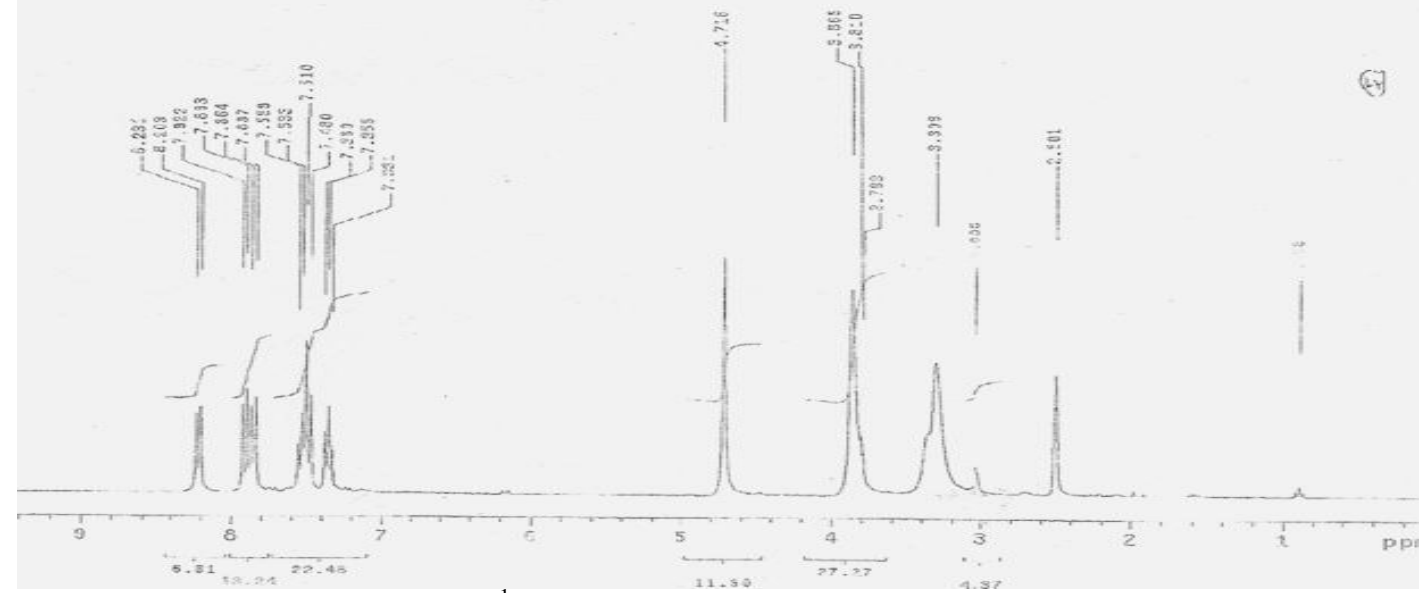

Fig15: ${ }^{1}$ HNMR spectrum of Mannich base IV

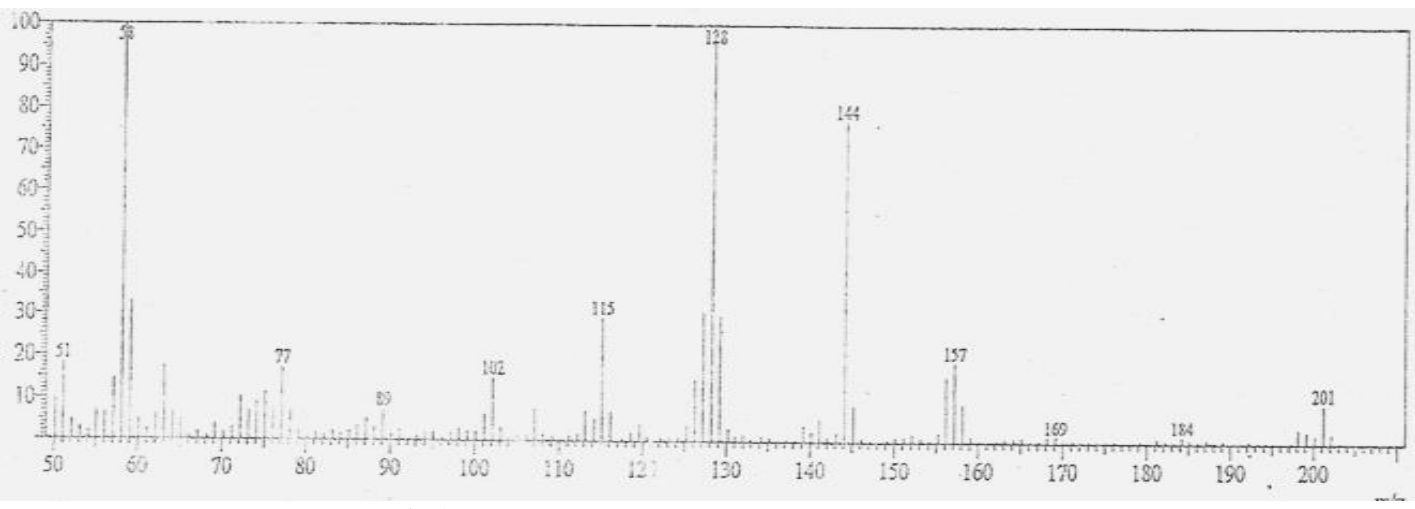

Fig16: The Mass spectrum of Mannich base IV

On the basis of the above spectral data structure IV above was assigned for this Mannich base. 


\section{Antimicrobial activity:-}

The target molecules were evaluated for their antimicrobial activity using the cup plate agar diffusion method.The average of the diameters of the growth inhibition zones are shown in Table (2) .The results were interpreted in commonly used terms : $13-18 \mathrm{~mm}$ growth inhibition zones is considered to be active; more than $18 \mathrm{~mm}$ : very active. Values less than $9 \mathrm{~mm}$ indicate inactivity.Values ranging from 9-12 indicate partial activity. Tables (3) and (4) represent the antimicrobial activity of standard antibacterial and antifungal chemotherapeutic agents against standard bacteria and fungi respectively.

Compound IV showed excellent antibacterial activity against all test organisms. It was also active against the fungal species Aspergillus niger. The same trend was observed for compound II which showed activity against both fungal species. Compound I demonstrated significant activity against Staphylococcus aureus. Compound III showed different promising antimicrobial responses( Table 2).

Table 2 : Antimicrobial activity of synthesized compounds :M.D.I.Z (mm)

\begin{tabular}{|l|l|l|l|l|l|l|l|}
\hline Compd. & Conc. $(\mathrm{mg} / \mathrm{ml})$ & Ec & Pa & Sa & Bs & Ca & An \\
\hline I & 20 & - & 16 & 21 & 12 & 12 & 15 \\
\hline II & 20 & 20 & 17 & 18 & 21 & 16 & 15 \\
\hline III & 20 & 15 & 15 & 17 & 18 & 14 & 10 \\
\hline IV & 20 & 24 & 26 & 26 & 26 & - & 15 \\
\hline
\end{tabular}

Table 3 : Antibacterial activity of standard chemotherapeutic agents :M.D.I.Z (mm)

\begin{tabular}{|l|l|l|l|l|l|}
\hline Drug & Conc. mg/ml & Bs. & Sa. & Ec. & Pa \\
\hline Ampicillin & 40 & 15 & 30 & - & - \\
& 20 & 14 & 25 & - & - \\
& 10 & 11 & 15 & - & - \\
\hline Gentamycin & 40 & 25 & 19 & 22 & 21 \\
& 20 & 22 & 18 & 18 & 15 \\
& 10 & 17 & 14 & 15 & 12 \\
\hline
\end{tabular}

Table 4 : Antifungal activity of standard chemotherapeutic agents against standard fungi

\begin{tabular}{|l|l|l|l|}
\hline Drug & Conc. $\mathrm{mg} / \mathrm{ml}$ & An. & Ca. \\
\hline Clotrimazole & 30 & 22 & 38 \\
& 15 & 17 & 31 \\
& 7.5 & 16 & 29 \\
\hline
\end{tabular}

- S.a: Staphylococcus aureus

- E.c: Escherichia coli

- P.a: Pseudomonas aeruginosa

- A.n: Aspergillus niger

- C.a: Candida albicans

- B.a: Bacillus subtilis

\section{Acknowledgement:-}

The research leading to these results has received funding from the Deutscher Akademischer Austausch Dienst (DAAD)- German Academic Exchange Service.

\section{References:-}

1. Archana,K.B. and Kumar,A.(2004), European Journal Medicinal Chemistry,39,369.

2. Abid-Abdulroouf,M.B., and ,Azam,A(2009)., European Journal Medicinal Chemistry,44,417.

3. Barijesh,K.S.,Prashant,B.K. and Kapandnis,V.L(2004)., European Journal Medicinal Chemistry,39,989.

4. Chipeleme,A. and Philip,J.(2007), Bioorganic and Medicinal Chemistry,15,273.

5. Delarue,S.,Emilia,C ,Louis,P. and Patricia,M(2008)., European Journal Medicinal Chemistry,4,252.

6. Dimmock,J.R.,Kumar,P.,Quail,J.W.,Allen,T.M.,Kao,G.Y.(1995), Eur.J.Chem,30,209.

7. Dimmock,J.R.,Kumar,P.,Eliud,A.N.(2000)., Eur.J.Chem,15,967.

8. Gul,I.H.,Vepsalainen,J.,Gul,M(2000).,Erciyas,E.,Pharmaceutica.Acta.Helvetiae, 74,393.

9. Jonathan,R.,Amitaabh,J.,Gordon,P.K.,Zello,A.,Quail,W.(2002),Eur.J.Chem,37,135. 
10. Kaylene,J., Stocks,A.,Paul,M.O.,Kevin-Park,B.(1999), J.Med.Chem,42,2747.

11. Li-Zhong,Y.,Yang,S.,Zhang,H. and Jun-Cao,B.(2003), Bioorganic and Medicinal Chemistry,11,4363

12. Lorand,T. and Kocsis,B.(2002), European Journal Medicinal Chemistry,37,804.

13. Laura,G. , Stefania,A..,Barbuceanu,F. and ,Eva,R.A.(2009), European Journal Medicinal Chemistry,44,3083.

14. Pernak,J.,Mirska,I. and Kmiecik,R.(1999),Eur.J.Med.Chem,34,765.

15. Pandeya,S.N.,Sriram,D.,Declercq,E(1999a).,Pharmaceutica.Acta.Helvetiae, 74,111.

16. Pandeya,S.N.,Nath,G.(1999b), E,European Journal Of Pharmaceutical Sciences,9,25.

17. Surendra,N.P.,Dhamrajan,S.,Gobal,N.(2000), Eur.J.Med.Chem,35,249.

18. Wikler, M. A., ed. "Performance Standards for Antimicrobial Susceptibility Testing: Seventeenth Informational Supplement, Clinical and Laboratory Standards Institute (2007). 